\title{
イモムシの動作を模做した管内走行ロボット
}

\section{Fabrication of a Green Caterpillar type In-Pipe Mobile Robot}

\author{
○学 後藤 幸也（日本工大院） 正 大野 学 (都立高専) \\ 正 伊藤 周三 (都立高専) 正 加藤 重雄（日本工大）
}

Yukiya GOTO, Nippon Institute of Technology, Miyashiro, Saitama, 345-8501

Manabu ONO, Tokyo Metropolitan College of Industrial Technology, Shinagawa, Tokyo, 140-0011

Shuzo ITO, Tokyo Metropolitan College of Industrial Technology

Shigeo KATO, Nippon Institute of Technology

\begin{abstract}
We have many small diameter pipes that are cooling pipes for atomic power stations, boiler pipes, and gas or water pipe lines. They must be periodically inspected in order to protect the accident previously. Diameters of these pipes are different at the place where pipes change from the main to the branch and a step comes here. The inspection robot for these pipes must move different diameter and go over the step. We propose a mobile robot that imitates the moving of a green caterpillar. The robot is constructed by the eight parallel rubber bellows and three suction brakes. The fabricated mobile robot was confirmed to move in different diameter pipes whose diameters are more than $70 \mathrm{~mm}$. Its speed was $16 \mathrm{~mm} / \mathrm{s}$.
\end{abstract}

Key words: A green caterpillar, In-pipe, Robot, Bellows, Suction brake

\section{1. 緒 言}

各種プラントに使用される配管は，傷や腐食が原因で流体 漏れを起こしている，配管は，断熱材などに覆われているた め, 外部からの検查が困難である.そのため, 配管内部を走 行することで検査を行うための管内走行ロボットを提案して いる[1][2]。これらのロボットは, 内径が一定の管内におい て $100 \mathrm{~m}$ 以上の長距離走行が可能である. しかし, 口ボット の足の役割をする管保持機構が検査対象管の径に合わせて設 計されるため，ガス管や水道管などに存在する本管と支管の 内径が異なる管への対応や，本管と支管の接続箇所に存在す る段差への対応が不可能である。

これまでに，様々な内径の管から構成される配管を走行す るため，吸着ブレーキを適用したロボットを提案している [3]. 吸着ブレーキは, 負圧力により管を吸着し, 大気圧解 放により吸着の解除を行うことができる. そのため，ロボッ トより大きい内径 $70 \mathrm{~mm}$ 以上の管を走行することが可能と なった。

今回，イモムシ（キアゲ八の終齢幼虫）の移動動作に着目 し，観察を行った，イモムシは，腹部を波打つように動か寸 ことで, 葉から葉へと小さな段差を移動する。この動作を模 倣するため, 空気圧アクチュエータであるべローズ 4 本を一 組の体節とした。これにより，体節は伸縮と屈曲動作を行う ことが可能となる。この体節 2 個と 3 個の吸着ブレーキから 構成されたロボットは, 内径 $70 \mathrm{~mm}$ 以上の管を $16 \mathrm{~mm} / \mathrm{s}$ で走 行することが確認できた。また，イモムシの動作を模倣する ことにより， $5 \mathrm{~mm}$ の段差に対応できたので報告する.

\section{2. イモムシについて}

イモムシの写真を図 1 に示す。イモムシは, 頭部と胸部, 腹部から構成される.胸部には 3 対のアシがあり, 腹部には 5 対のハラアシがある。八ラアシは節がなく，短い円筒形で先 端には爪が多数あり, 対象物に引っ掛けることができ, 吸着 することもできる.

イモムシの動作を観察し，その簡単な動作を図 2 に示す. イモムシは頭部と胸部で移動方向を決め, 腹部を波打つよう に動かし，腹アシを後ろから前へと吸着させることにより移 動していく．イモムシは腹部のハラアシをすべて吸着させ, 静止している。これを初期状態とし，(a)とする.

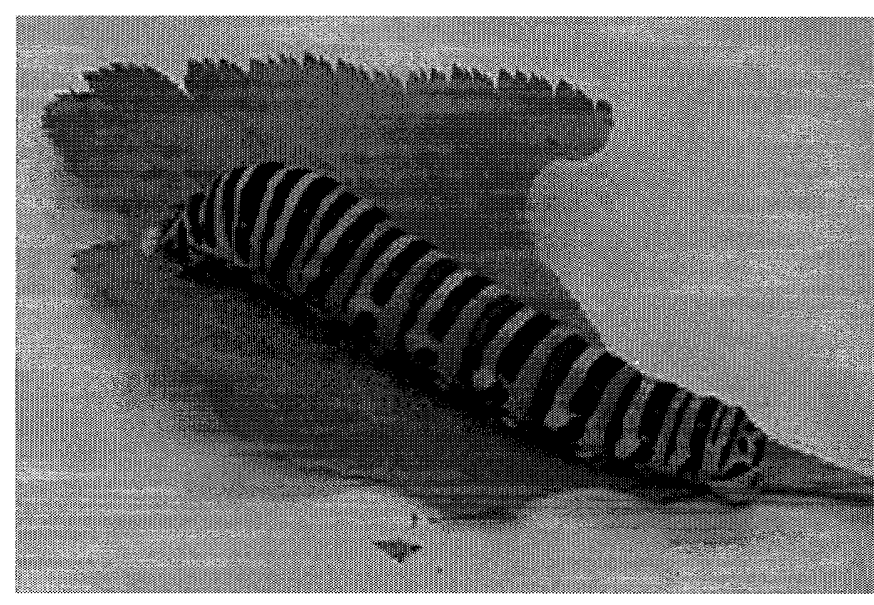

Fig. 1 A green caterpillar

(a)

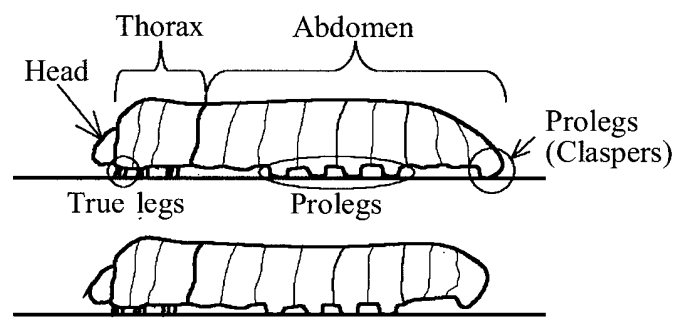

(c)

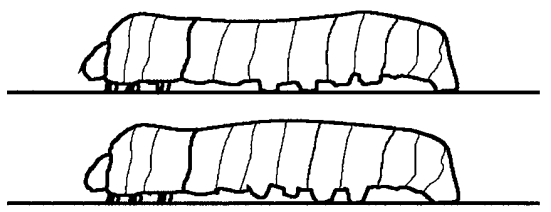

(e)

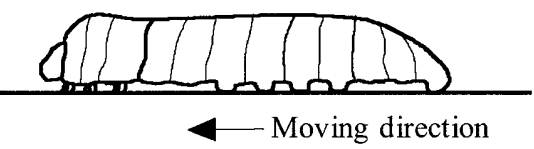

Fig. 2 Moving of a green caterpillar 
(b)イモムシは最後部のハラアシを蹴り上げ，腹部の後方を 縮める.

(c)イモムシは最後部のハラアシを吸着させ, (b)で縮められ た腹部を元に戻すため, 中央部のハラアシを蹴り上げる. それにより腹部の中央が縮められる。

(d)イモムシは中央部のハラアシを吸着させ，(c)で縮められ た腹部を元に戻すため，前部のハラアシを蹴り上げる。そ れにより腹部の前方が縮められる。

(e)イモムシは前部のハラアシを吸着させ，(d)で縮められた 腹部を元に戻すことで，胸部を移動方向に押し出す。

イモムシは，このように腹部を波打つように動かし，八ラ アシを吸着させることで移動する.また，この波打つ動きに より，葉から葉へと小さな段差を移動することもできる.

\section{3. ロボットの構造}

試作したロボットの構造を図 3 に示す。ロボットは，2 個 の体節と 3 個の吸着ブレーキから構成される。体節は 4 本の ベローズを 2 行 2 列のマトリクス状に配置している. ベロー

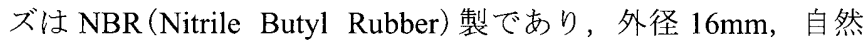
長 $76 \mathrm{~mm}$ である。 上側 2 個のベローズは, 1 本の空気供給チ ューブにより配管され，同じ空気室となっている。下側 2 個 のベローズも同様である. 吸着ブレーキは直径 $40 \mathrm{~mm}$ の NBR 製吸盤である。その中心には空気供給チューブが接続され， ロボットの前後と中心の 3 箇所に配置される.

\section{4. ロボットの動作確認}

ロボットは空気圧による体節の伸縮・屈曲動作と吸着ブ レーキの吸着動作を利用して管内を走行する。ロボットが 管内を走行する際の初期状態を図 4 に示す。ロボットは 2 個の体節を伸張させ，3 個の吸着ブレーキを管に吸着させ,

静止している

\section{1 体節の功作}

体節の動作を図 5 に示す。体節はベローズより構成され る。ベローズは正圧力を供給することで伸張し，負圧力を 供給することで収縮する。体節の上側と下側のベローズに 正圧力を供給することで，体節は伸張する。 また，負圧力 を供給することで体節は収縮する。さらに，体節の上側心゙ ローズに正圧力，下側ベローズに負圧力を供給することで， 体節は屈曲することも可能となる。この体節の伸縮と屈曲 動作を行うことで，イモムシの波打つ動きを模倣すること ができる，そして，この波打つ動きにより吸着ブレーキを 管に押し付ける。 また，吸着ブレーキを持ち上げる働きも する。

\section{2 ロボットの功作}

ロボットを内径 $79 \mathrm{~mm}$ の管で走行させたときの吸着ブレ 一キ内の圧力変化を測定した。その結果を図 6 に示す。ロボ ットは図 7 に示す動作原理により走行する。ロボットには正 圧力 $+20 \mathrm{kPa}$ ，負圧力- $80 \mathrm{kPa}$ が供給されている.

図 6 に掠いて，吸着ブレーキは圧力が負圧のとき管に吸 着し，0kPaのとき管を離していることを示している。また， 図 7 において，吸着ブレーキが管を離しているときを白色 で示し，吸着しているときを黑色で示す。

ステップ 1 : 動作開始から $0.2 \mathrm{~s}$ 間, 後方の吸着ブレーキを管 から離し，後部体節を屈曲させながら収縮させ る。それにより進行方向に後方の吸着ブレーキ が移動する，その後，後方の吸着ブレーキを管 に吸着させる。

ステップ 2 : 動作開始から $0.6 \mathrm{~s}$ 後, 中央の吸着ブレーキが管 を離す，それに伴い，前部体節を収縮させ，後 部体節を伸張させる。 その後, 中央の吸着ブレ 一キを管に吸着させる。

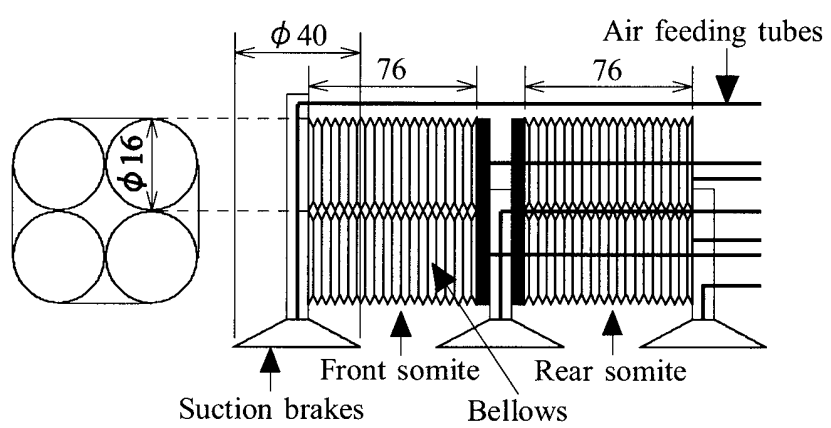

Fig. 3 Structure of in-pipe mobile robot

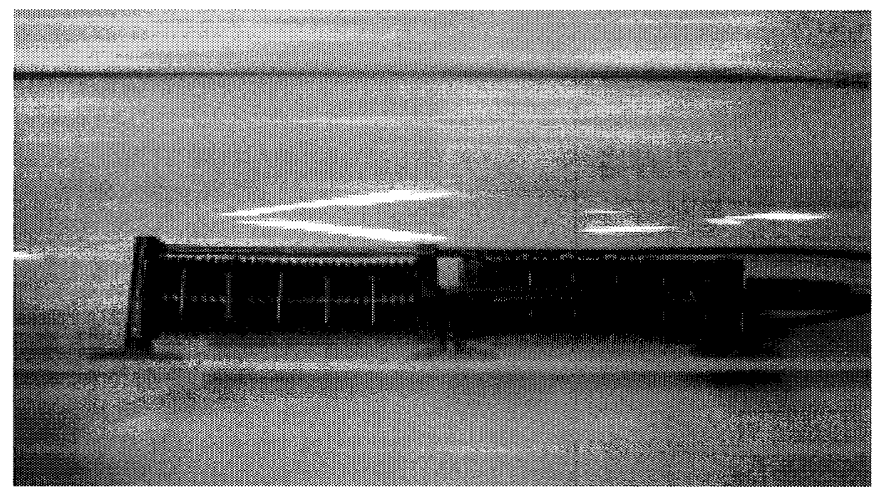

Fig. 4 Initial condition of robot in the acrylic pipe

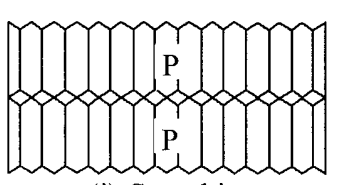

(i) Stretching

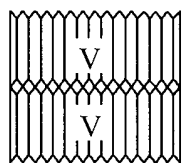

(ii) Shrinking

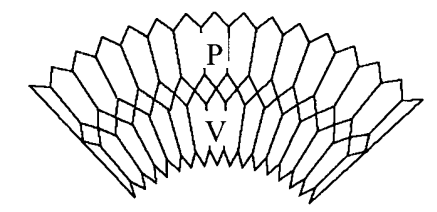

(iii) Bending

Fig. 5 Moving principle of somite

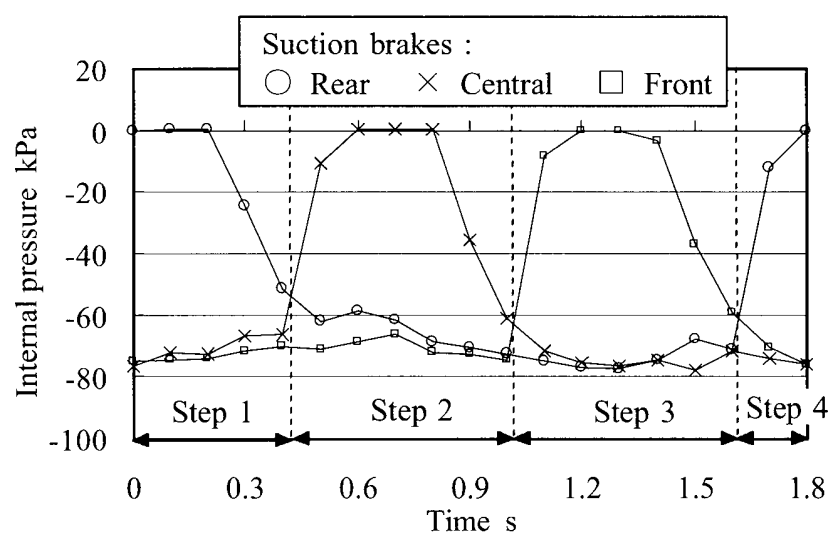

Fig. 6 Internal pressure in the suction brakes 


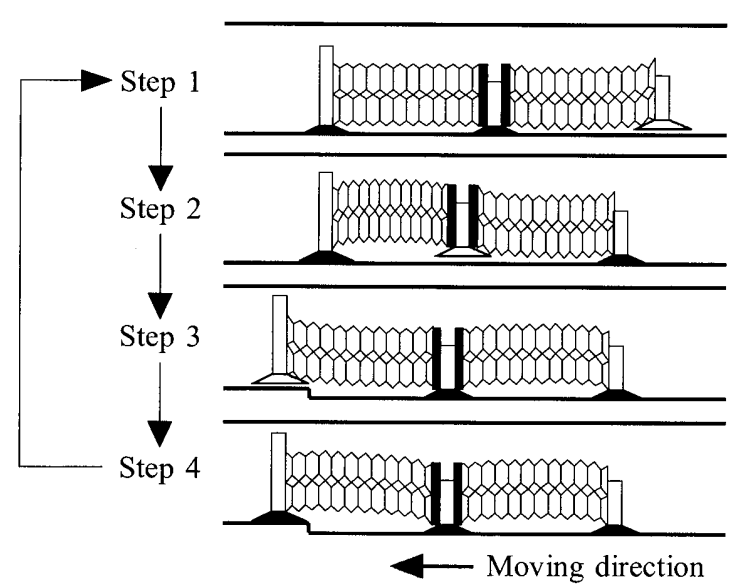

Fig. 7 Moving principle of in-pipe mobile robot

ステップ 3 : 前方の吸着ブレーキを管から離し，前部体節を 屈曲させながら伸張し，前方の吸着ブレーキを 進行方向に移動する.

ステップ 4: 動作開始から $1.5 \mathrm{~s}$ の時，前方の吸着ブレーキが 管を吸着し，ロボットは静止する。ここで，口 ボット全体が進行方向に移動したことになる.

ロボットはイモムシのように体節を波打つように動かし， 後方から前方へと吸着ブレ一キを吸着させていくことで，管 内を走行することが確認できた。

\section{5. 走行実験}

管の内径別走行速度の実験結果を図 8 に示す。実験は，内 径 $70 \mathrm{~mm}$ から内径 $150 \mathrm{~mm}$ の管を水平に設置し，それぞれの 走行速度を測定した。ロボットの走行速度は，管の内径によ って大きな変化はなく, 平均值は $16 \mathrm{~mm} / \mathrm{s}$ であった。

ロボットは内径 $110 \mathrm{~mm}$ と内径 $120 \mathrm{~mm}$ の管を接続したと きにできる $5 \mathrm{~mm}$ の段差を通過することが確認できた。その ときの様子を図 9 に示寸。ロロボットは，体節を波打つように 動かすことで段差を通過した。

\section{6. 結 言}

本研究をまとめると以下のようになる.

（1）イモムシの移動動作を観察した結果，イモムシは腹部を 波打つように動かし，八ラアシを吸着させることで移動 することがわかった。

（2）試作したロボットは，ベローズ 4 本を一組の体節とする ことで，伸縮と屈曲動作を行うことが可能となり，これ によりイモムシの波打つ動きを模倣することができた.

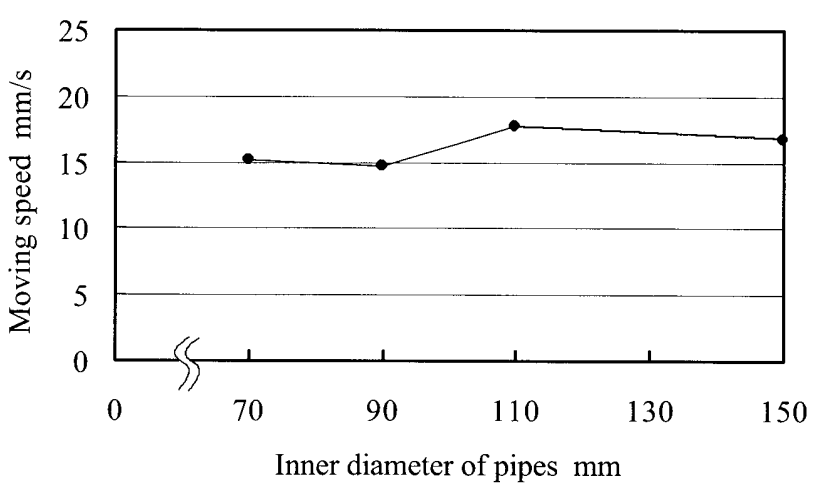

Fig. 8 Moving speed of robot

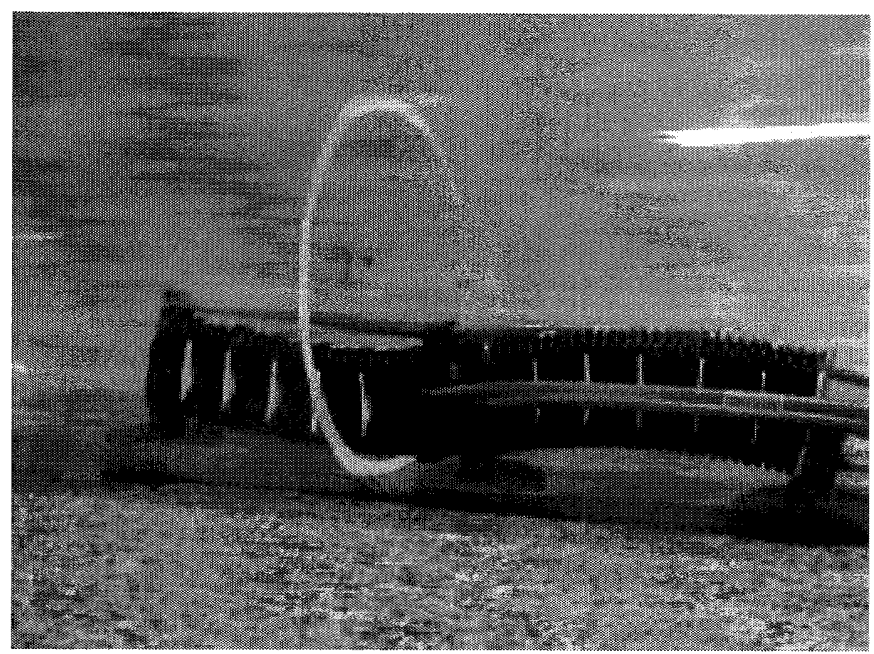

Fig. 9 Moving robot in different diameter of pipes

（3）イモムシの動作を模倣したロボットは，管を吸着するこ とで内径 $70 \mathrm{~mm}$ 以上の管を $16 \mathrm{~mm} / \mathrm{s}$ で走行することが確 認できた。また，イモムシの波打つ動きを模倣したこと で，5mmの段差を通過することも確認できた。

\section{参考文献}

[1] 大野学, 加藤重雄, 精密工学会誌, Vol. 71, No. 5, pp. 606-612, 2005

[2] M. ONO, T. HAMANO and S. KATO, Modeling and Fabrication of a Mobile Inspection Microrobot Driven by a Pneumatic Bellows Actuator for Long Pipes, Journal of Robotics and Mechatronics Vol. 18, No. 1, pp. 11-17, 2006

[3] 後藤ほか, 日本機械学会東北支部第 43 期総会・講演会, 講演論文集 $(2007)$, pp. 13-14 